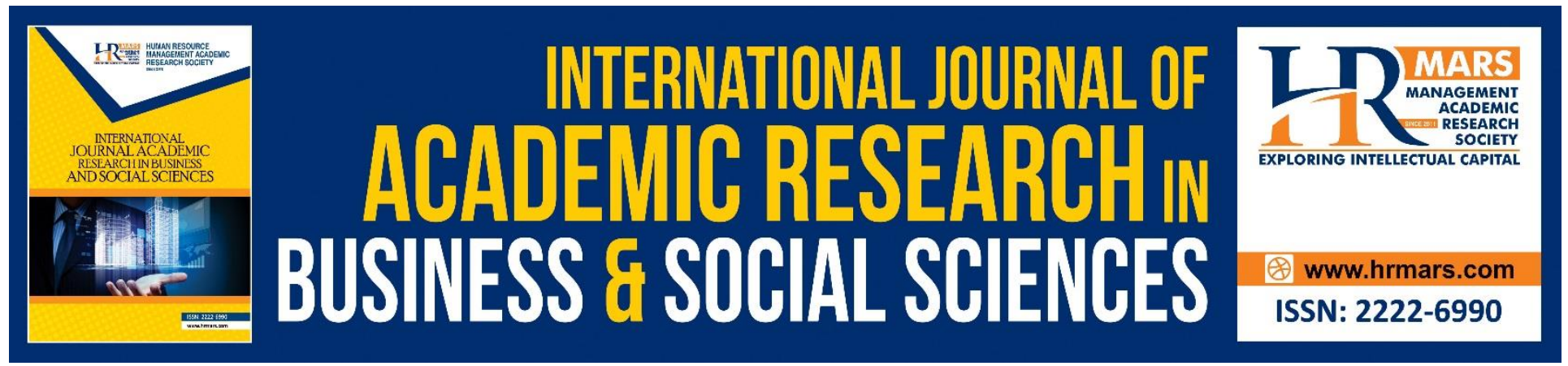

\title{
Relationship between Social Capital and Mental Health on Quality of Life among Low Income Group (B40) in Terengganu
}

\begin{abstract}
Aziz Amin, Zainul Zolkifeli, Mohamad Fauzi Abdul Latib, Ahmad Puad Mat Som
\end{abstract}

To Link this Article: http://dx.doi.org/10.6007/IJARBSS/v8-i9/4698

DOI: $\quad 10.6007 /$ IJARBSS/v8-i9/4698

Received: 16 August 2018, Revised: 09 Sept 2018, Accepted: 29 Sept 2018

Published Online: 15 October 2018

In-Text Citation: (Amin, Zolkifeli, Latib, \& Som, 2018)

To Cite this Article: Amin, A., Zolkifeli, Z., Latib, M. F. A., \& Som, A. P. M. (2018). Relationship between Social Capital and Mental Health on Quality of Life among Low Income Group (B40) in Terengganu. International Journal of Academic Research in Business and Social Sciences, 8(9), 1309-1320.

\section{Copyright: (C) 2018 The Author(s)}

Published by Human Resource Management Academic Research Society (www.hrmars.com)

This article is published under the Creative Commons Attribution (CC BY 4.0) license. Anyone may reproduce, distribute, translate and create derivative works of this article (for both commercial and non-commercial purposes), subject to full attribution to the original publication and authors. The full terms of this license may be seen at: $\underline{\text { http://creativecommons.org/licences/by/4.0/legalcode }}$

Vol. 8, No. 9, September 2018, Pg. 1309 - 1320

Full Terms \& Conditions of access and use can be found at http://hrmars.com/index.php/pages/detail/publication-ethics 


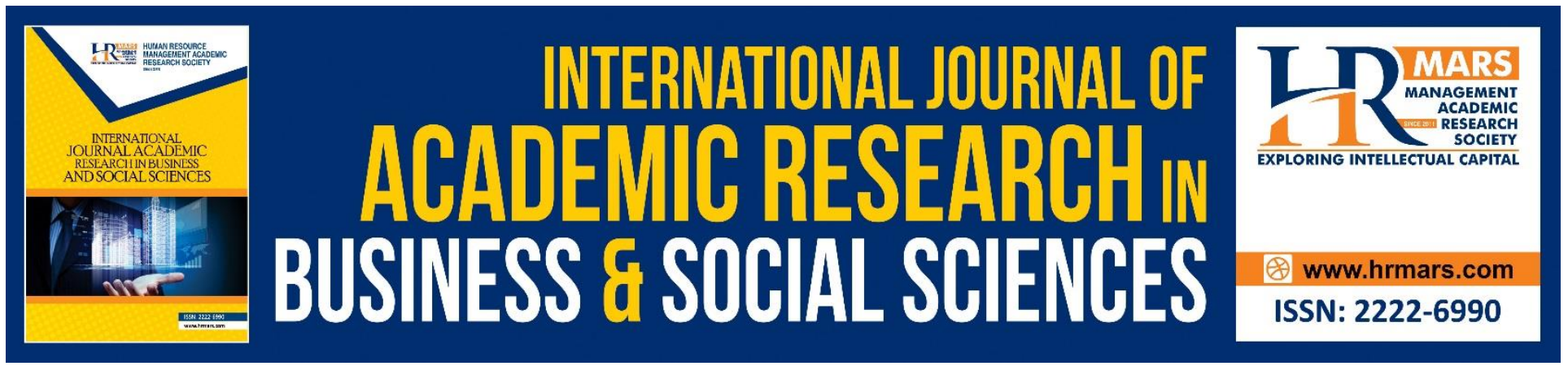

\title{
Relationship between Social Capital and Mental Health on Quality of Life among Low Income Group (B40) in Terengganu
}

\author{
Aziz Amin \\ Faculty of Applied Social Sciences, Universiti Sultan Zainal Abidin \\ Malaysia \\ Email: wanazizmn@unisza.edu.my \\ Zainul Zolkifeli \\ Faculty of Applied Social Sciences, Universiti Sultan Zainal Abidin \\ Malaysia \\ Email: zainulzolkifeli@gmail.com \\ Mohamad Fauzi Abdul Latib \\ Faculty of Applied Social Sciences, Universiti Sultan Zainal Abidin \\ Malaysia \\ Email: fauzilatib@unisza.edu.my \\ Ahmad Puad Mat Som \\ Faculty of Applied Social Sciences, Universiti Sultan Zainal Abidin \\ Malaysia \\ Email: puadms@unisza.edu.my
}

\begin{abstract}
Quality of life is an issue frequently discussed among social researchers as it can negatively affect one's life and affect an individual's mental health. This issue relates closely to the factors of economy and income. In 2015, the Department of Statistics recorded 2.7 million of the B40 income group, with $63 \%$ living in the city while $37 \%$ lived outside the city. In 2014, the Economic Planning Unit reported the average monthly income for this group as RM2,537, which is $80 \%$ lower compared to the monthly average salary of households in Malaysia of RM6,141. The income for this group is also found to be five times lower from the average income for T20 (RM14,305) and twice as low the average income for M40 (RM5,662). The B40 group faces pressure from high living costs. Their average income of
\end{abstract}


INTERNATIONAL JOURNAL OF ACADEMIC RESEARCH IN BUSINESS AND SOCIAL SCIENCES

Vol. 8, No. 9, Sept. 2018, E-ISSN: 2222-6990 @ 2018 HRMARS

$\mathrm{RM} 2,537$ is lower than the mean monthly household consumption expenditure by RM3,578 with $29 \%$ of households have expenditure higher than income. This income and spending mismatch can affect the quality of life for the B40 group if no measures are taken to resolve this. The income for the B40 group averages below RM3,860 a month. The creation of an index for the low-income target group that is comprehensive is needed to form the foundations of social and economic development in the future. The objective of this research was to study the relationship between social capital and mental health towards the quality of life for the low-income group B40. Initial research was in the form of survey involving 100 households in Kuala Terengganu, Malaysia. Data analysis was conducted using SPSS software. This study can contribute to the formulation of national policies regarding social welfare especially for the lower income groups.

Keywords: Quality of Life, Social Capital, Mental Health, Low-Income Group

\section{Introduction}

Continuous improvement to the quality of life of the people is the measure of a nation's development (Mahathir, 1999). Various efforts have been made by the government to provide employment opportunities, housing assistance, health services, improvements in education, all aimed at improving the people's quality of life. However, not everyone is able to enjoy the benefits. According to Muhyiddin (2004), the World Bank has identified Malaysia's economy as being at a successful level but there are still some of the people not enjoying a good quality of life in line with the current economic situation of the country. Statistics put forth by the Economic Planning Unit in 2014, that is the average daily income of the low-income group or B40 group as RM 2,537 or $80 \%$ lower compared to the national average household income for Malaysia of RM 6,141. According to Nor Hamizah (2016), based on statistics by the Department of Statistics in 2015, as many as 2.7 million people are in the B40 group in Malaysia. Therefore, this study aims to determine how far the element of social capital can influence the quality of life in Terengganu. Apart from that, mental health is also a factor to be studied as a moderator.

\section{Literature Review}

Definition and Concept

Research on the quality of life has been much discussed by previous researchers before this.

Among them, Muhamad Fadhil (2003) stated that quality of life is a method to resolve problems and further improve life in terms of safety, health, social and psychology. Quality of life can be divided into two, namely objective quality of life and subjective quality of life (Norizan, 2003). Objective quality of life is something that can be seen externally and can be achieved by an individual such as housing, health, education and income. Subjective quality of life is something that cannot be seen externally such as satisfaction and enjoyment of life such as happiness, gratitude and joy from certain things. Research by Siti Fatimah (2005) emphasised that the concept of quality of life cannot be measured just by material things just as property, a good job or high level of education but it also involves other elements such as peace of mind, love and empathy for other fellow human beings. Apart from this, researchers such as Norizan (2003), Polnac et al. (2001) and Calvert et al. (2000) used several factors such work environment, family, safety, peacefulness, transportation, communication, housing, health, income, education and social participation to measure one's quality of life. 
In discussions about social capital, many previous studies have explained the concept of social capital. Coleman (1999), stated that social capital is the ability of the community to work together, to achieve a common goal, in various groups and organisations. Bullen \& Onyx (2005) used eight measure indicators, namely community participation, social activity, trust, neighbourhood, family relationships, tolerance, life values, and employment. Meanwhile, The Barometer of Social Capital Colombia by Sudarsky (1999) also stressed on eight indicators, namely belief in organisations, participation, dependency on each other, civil government political participation, hierarchy, social regulation and flat relationship. The measurement of Integrated Questionnaire for The Measurement of Social Capital (SC-IQ) by Grootaert, Narayan, Jones, \& Woolcock (2004) uses six indicators, namely working network, trust, cooperation, information and communication, unity and social inclusivity and empowerment. Studies about the ability of social capital is still lacking in this country. Among those available is a study of the definition of social capital or the study of the influence of social capital of competitiveness (Noorasiah \& Mohd Nasir, 2007; Bjornskov \& Svendsen, 2003; Grootaert et al., 2004). A study by Rahmah et al., (2016) used three indicators, namely relationships and network, trust, and cultural and life norms based on the World Bank Integrated Social Capital Survey by Grootaert et al., (2004).

According to HealthPro (2000), a bulletin published by the Department of Community of Universiti Kebangsaan Malaysia, mental health relates closely to every aspect of an individual's life. This is in line with the explanation by Warr (1987) that highlights the Vitamin Model that according to him, mental health depends on interaction between an individual and their environment. He also states that in today's modern society, work environment is also an important aspect. According to WHO (2003), more than 450 million are experiencing mental health issues in the world today. 10\% from this figure is behavioural and mental disorders due to global diseases. In 2020, this figure is expected to increase to $15 \%$. In a study of the relationship between mental health and individuals and its connection with social capital, DeSilva et al. (2005) stated that there is solid evidence in Malaysia that there are adults with opposite levels of individual cognitiveness for social capital and mental health. Mental health is a very important aspect in one's life apart from spiritual, physical, and financial health. Mental health is also the key to an individual gaining satisfaction in life (Swami et al., 2007). Issues such as these must be given serious attention as it involves effects on the individual, community and country. Therefore, the mental health of the B40 group may be affected and could influence quality of life due to economic stress and financial factors.

\section{Relationship between Social Capital and Quality of Life}

In today's technologically advanced world, there is less face-to-face interaction among society, thus the role of social capital is clearer and even more significant as it is also said to be part of virtual capital (Ancok, 1998). Research done by experts from different social fields from various countries has found that social capital plays an important role in achieving economic success for a society (Gittell et al., 2001: 122). This research shows that social capital plays a role in creating cooperation between society and financial institutions that can help in the development of community ventures. This human capital approach is an alternative to economic development strategy by lower income groups that is usually supported by funds acquired from project support managed by the 
INTERNATIONAL JOURNAL OF ACADEMIC RESEARCH IN BUSINESS AND SOCIAL SCIENCES Vol. 8, No. 9, Sept. 2018, E-ISSN: 2222-6990 @ 2018 HRMARS

government. Robison et al., (2002) opined that in various aspects of the economy, the community with social capital gains more benefits compared to that which does not. They further opined that social capital is only the feeling of sympathy from an individual or a group towards another individual or group. This feeling of sympathy can be awe, caring, empathy, appreciation, responsibility, or trust towards an individual or a group (Robison et al., 2002: 5).

\section{Mental Health as a Moderator Variable}

Previous researchers have studied the effects of mental health as a moderator. For example, LU et al. (2017) found that mental health affected the relationship between social limitations and quality of sleep among Chinese-American breast cancer patients. Another study carried out by Krabbenborg et al. (2017) found that mental health also had an effect in the relationship between determining one's own path and quality of life among the adult homeless. Cha et al. (2017) found that there were intermediary effects of mental health in the relationship between stress and quality of life among cancer patients.

Apart from that, there have also been researchers who provide explanations regarding mental health as an intermediary to certain variables. As an example, Reimer (2014) found that mental health influences performance on the job and the decision to retire. Shrestha et al. (2017) found that intermediary effects of mental health between stigma related to HIV and quality of life in relation to health is semi-intermediary. Chung et al. (2013) found that mental health has a semi-intermediary effect in the relationship between difficulty and quality of life among heart patients. Gomez-Gallego, Gomez-Garcia, \& Ato Lozano (2017) found that mental health acts as a semi-intermediary between function and quality of life

Figure 1: Conceptual framework

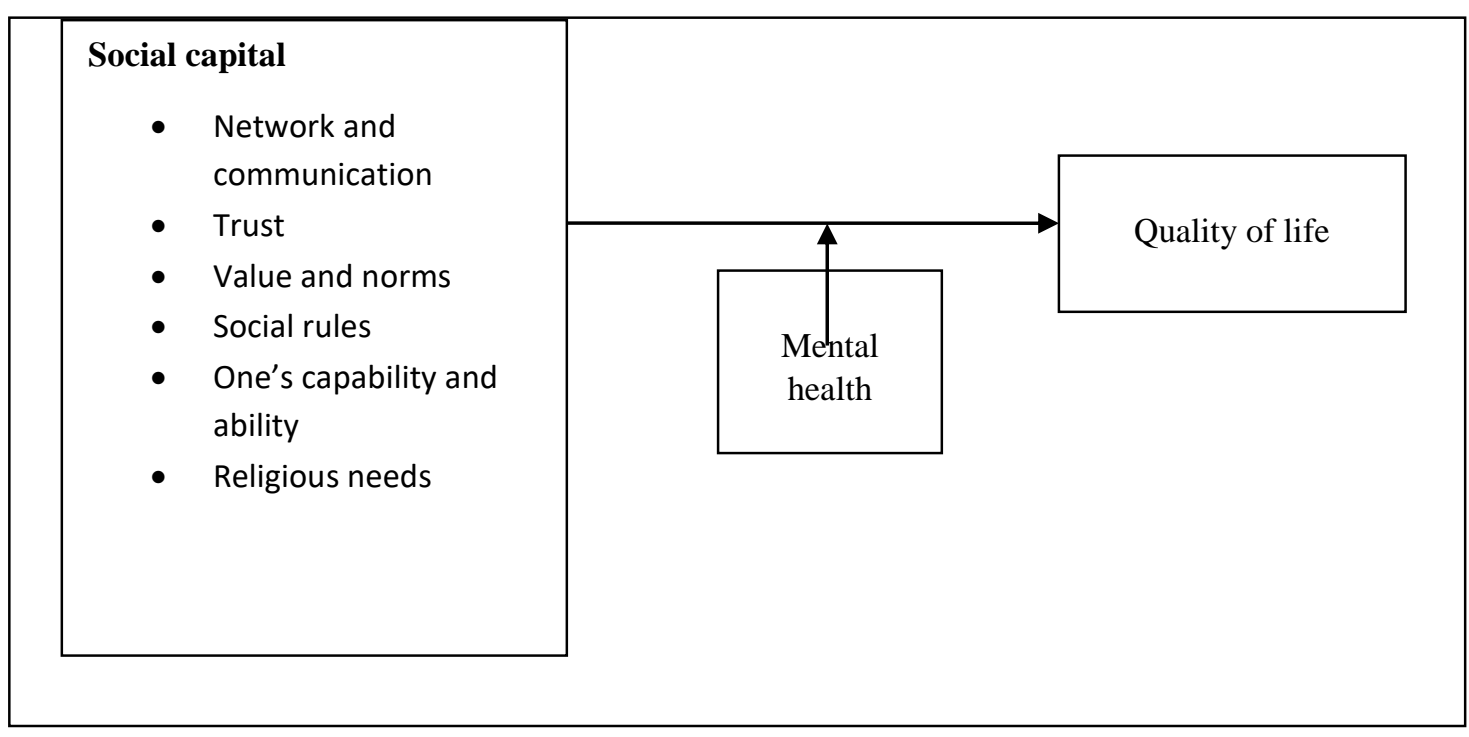


INTERNATIONAL JOURNAL OF ACADEMIC RESEARCH IN BUSINESS AND SOCIAL SCIENCES

Vol. 8, No. 9, Sept. 2018, E-ISSN: 2222-6990 (C) 2018 HRMARS

\section{Methodology}

Based on literature review and perspective of similar theory, this research proposes a concept framework as shown in Figure 1. Several determined variables that were used as hypothesis are shown in Figure 1. This study is quantitative in nature and was carried out on leaders of households in Kuala Terengganu. Survey forms focused on leaders of households were distributed to gather data regarding the elements of social capital, mental health and quality of life. This study applied the stratified random sampling technique based on household income for the B40 income group. 100 early study samples were chosen from the B40 income group in Kuala Terengganu and the data was processed and analysed using the Statistical Package for Social Science (SPSS). Among analyses carried out included the reliability test, descriptive analysis and inference.

\section{Reliability Test and Data Normality}

Based on Table 1, the value of Cronbach's Alpha for the items quality of life, mental health and social capital are $0.897,0.702$ and 0.849 respectively. All the values above are more than 0.6 , meaning that these items are suitable to be used and can be accepted for measurement (Sekaran, 2003). Normality tests also showed that data is normally distributed if the value of skewness and kurtosis is in the range of \pm 3 (Coakes \& Steed, 2007).

Table 1: Reliability Test Analysis Results

\begin{tabular}{|c|c|c|}
\hline Item & No. of Items & Cronbach's Alpha \\
\hline Quality of Life & 35 & 0.897 \\
\hline Mental Health & 5 & 0.702 \\
\hline Social Capital & 61 & 0.849 \\
\hline
\end{tabular}

\section{Results and Discussion}

Demographic Profile

The overall total number of respondents for this study is 100 . Based on Table 2 below, $87 \%$ are males and $13 \%$ are females. Based on age, 59\% of this study's respondents are aged between 36 and 50 years old. $95 \%$ of them are married. In terms of educational background, $62 \%$ of respondents have qualifications up to SPM level while $28 \%$ at STPM/Diploma level. 38\% of respondents are selfemployed while $36 \%$ of respondents work in the private sector. $28 \%$ of respondents have income of between RM1001 and RM2000 a month while the remaining 56\% have income of between RM2001 and RM3000 a month. 
INTERNATIONAL JOURNAL OF ACADEMIC RESEARCH IN BUSINESS AND SOCIAL SCIENCES Vol. 8, No. 9, Sept. 2018, E-ISSN: 2222-6990 @ 2018 HRMARS

Table 2: Demographic Profile of Respondents

\begin{tabular}{|c|c|c|c|}
\hline Demographic Profile & Category & Frequency & Percentage \\
\hline \multirow[t]{3}{*}{ Age } & 21 to 35 years & 35 & 35.0 \\
\hline & 36 to 50 years & 59 & 59.0 \\
\hline & 51 to 65 years & 6 & 6.0 \\
\hline \multirow[t]{2}{*}{ Sex } & Male & 87 & 87.0 \\
\hline & Female & 13 & 13.0 \\
\hline \multirow[t]{3}{*}{ Status } & Single & 4 & 4.0 \\
\hline & Married & 95 & 95.0 \\
\hline & Divorced & 1 & 1.0 \\
\hline \multirow[t]{4}{*}{ Education Level } & SRP/PMR & 2 & 2.0 \\
\hline & SPM & 62 & 62.0 \\
\hline & STPM/Diploma & 28 & 28.0 \\
\hline & $\begin{array}{l}\text { Graduate degree } \\
\text { and above }\end{array}$ & 8 & 8.0 \\
\hline \multirow[t]{6}{*}{ Employment } & Government & 25 & 25.0 \\
\hline & employee & 36 & 36.0 \\
\hline & Private sector & 38 & 38.0 \\
\hline & employee & 1 & 1.0 \\
\hline & Self-employed & & \\
\hline & Unemployed & & \\
\hline \multirow[t]{4}{*}{ Monthly income } & RM1-RM1000 & 4 & 4.0 \\
\hline & RM1001-RM2000 & 28 & 28.0 \\
\hline & RM2001-RM3000 & 56 & 56.0 \\
\hline & RM3001-RM4000 & 12 & 12.0 \\
\hline
\end{tabular}

Mean for Quality of Life, Mental Health and Social Capital

The mean capacity index for social capital is as per Table 3 where the measuring scale for this study is the value of 1 to 5 , where 1 represents a low measuring scale and 5 shows a high measuring scale. 
INTERNATIONAL JOURNAL OF ACADEMIC RESEARCH IN BUSINESS AND SOCIAL SCIENCES Vol. 8, No. 9, Sept. 2018, E-ISSN: 2222-6990 @ 2018 HRMARS

Table 3: Mean for Quality of Life, Mental Health and Social Capital

\begin{tabular}{lcccc}
\hline \multicolumn{1}{c}{ Variable } & Minimum & Maximum & Mean & SD \\
\hline Quality of Life & 2.49 & 4.54 & 3.914 & 0.304 \\
Mental Health & 3.00 & 4.60 & 4.222 & 0.286 \\
Network \& Communication & 3.00 & 4.45 & 3.593 & 0.203 \\
Trust & 2.80 & 4.50 & 4.001 & 0.444 \\
Value and Norms & 3.20 & 5.00 & 4.251 & 0.337 \\
Social Rules & 3.20 & 4.20 & 3.858 & 0.236 \\
Own Ability and Capability & 2.90 & 4.50 & 4.252 & 0.318 \\
Religious Needs & 3.00 & 5.00 & 4.343 & 0.269 \\
\hline
\end{tabular}

Based on Table 3, all variables of quality of life, mental health and social capital, that are network and communication; trust; value and norms; social rules; own ability and capability and religious needs show mean of more than 3 . This shows that the level of quality of life, mental health and social capital is high as the median for this scale is 3 . If the value is more than 3 , this is deemed good as it is nearing the value of 5. Otherwise, if the mean value is less than 3 , the level of that variable is considered low as the value is nearing the minimum value of 1 . This measuring scale refers to the study done by Mohd Shaladdin, Wan Abd Aziz, \& Nik Wan (2009). Therefore, it is determined that all variables for the B40 income group, i.e. quality of life, mental health and social capital are at a high level.

Correlation Analysis Between Social Capital and Quality of Life of the B40 Group

Table 4: Correlation

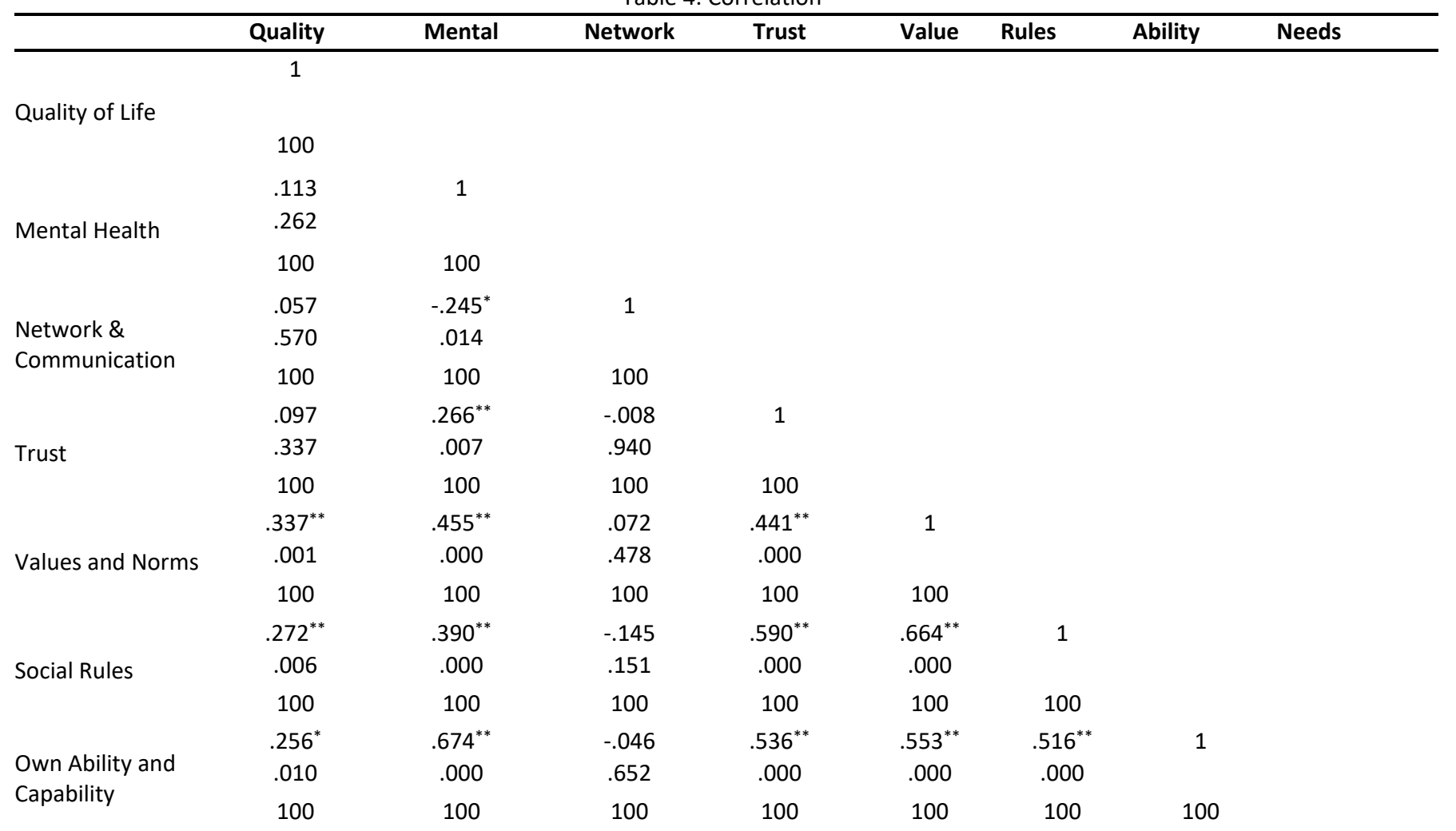


INTERNATIONAL JOURNAL OF ACADEMIC RESEARCH IN BUSINESS AND SOCIAL SCIENCES

Vol. 8, No. 9, Sept. 2018, E-ISSN: 2222-6990 @ 2018 HRMARS

\begin{tabular}{lccccccccc} 
& $.284^{* *}$ & $.497^{* *}$ & .149 & $.397^{* *}$ & $.264^{* *}$ & $.225^{*}$ & $.502^{* *}$ & 1 \\
Religious Needs & .004 & .000 & .138 & .000 & .008 & .024 & .000 & 100 \\
& 100 & 100 & 100 & 100 & 100 & 100 & 100 \\
\hline
\end{tabular}

**. Correlation is significant at $\mathrm{p}<0.01$ (2-tailed).

*. Correlation is significant at $p<0.05$ (2-tailed).

Table 4 shows the correlation analysis between social capital and quality of life for the B40 group in Kuala Terengganu. Based on the table, it is found that four of the social capital dimensions i.e. values and norms, social rules, own ability and capability and religious needs have significant correlation with quality of life of the B40 group. The four factors are each significant at 0.01 (2-tailed) and significant at 0.05 (2-tailed), and at the same time all the factors have positive values. Therefore, this shows that these dimensions can influence the quality of life of the B40 group in Kuala Terengganu According to the Connolly and Sluckin Estimation Table, the strength of the relationship of four of these social capital dimensions are at a medium level i.e. value of $r$ between 0.1 and 0.4 (Mohd Shaladdin et al., 2009). The results of the study showed that there are two of the social capital dimensions i.e. network and communication as well as trust that do not have a significant correlation with quality of life. However, the relationship is positive, meaning that if these dimensions were improved on, these would also be able to influence the quality of life of the B40 group.

Analysis on the Role of Mental Health as a Moderator to the Relationship Between Social Capital and Quality of Life

Based on the concept framework of this study, the social capital dimension is the influencing factor for quality of life, while mental health acts as moderator towards the relationship between social capital and quality of life. A semi-correlation analysis was used to see the role of moderator in this relationship. The results of the analysis are as shown in Table 5.

Table 5: Semi-correlation

\begin{tabular}{lcc}
\hline \multicolumn{1}{c}{ Social Capital } & Zero correlation & Semi-correlation \\
\hline Network and communication & 0.057 & 0.088 \\
Trust & 0.097 & 0.070 \\
Value and norms & 0.337 & 0.322 \\
Social rules & 0.272 & 0.250 \\
One's capability or ability & 0.256 & 0.245 \\
Religious needs & 0.284 & 0.264 \\
\hline
\end{tabular}

* Semi-correlation when the variable of mental health is controlled

Based on Table 5, the value of the correlation coefficient for the dimension of network and communication rises to 0.088 from 0.057 when the variable for mental health is controlled. 
Therefore, in this relationship mental health influences the dependent variable of quality of life. Meanwhile, for other dimensions of trust, values and norms, social rules, one's capability or ability, and religious needs, all the respective correlation coefficients show a decrease. Therefore, mental health has influenced both independent and dependent variables. This means that mental health is the moderator to the relationship between social capital and quality of life.

The Influence of Social Capital on the Respondents' Quality of Life

Results from the regression analysis show the influence of the independent variable, the social capital factor, on the quality of life of the respondents. Based on the correlation analysis, two factors show values that are not significant, namely network \& communication and trust (refer to Table 4). Only the factors that have significant correlation values can their influence be measured using regression analysis.

Table 6: Regression

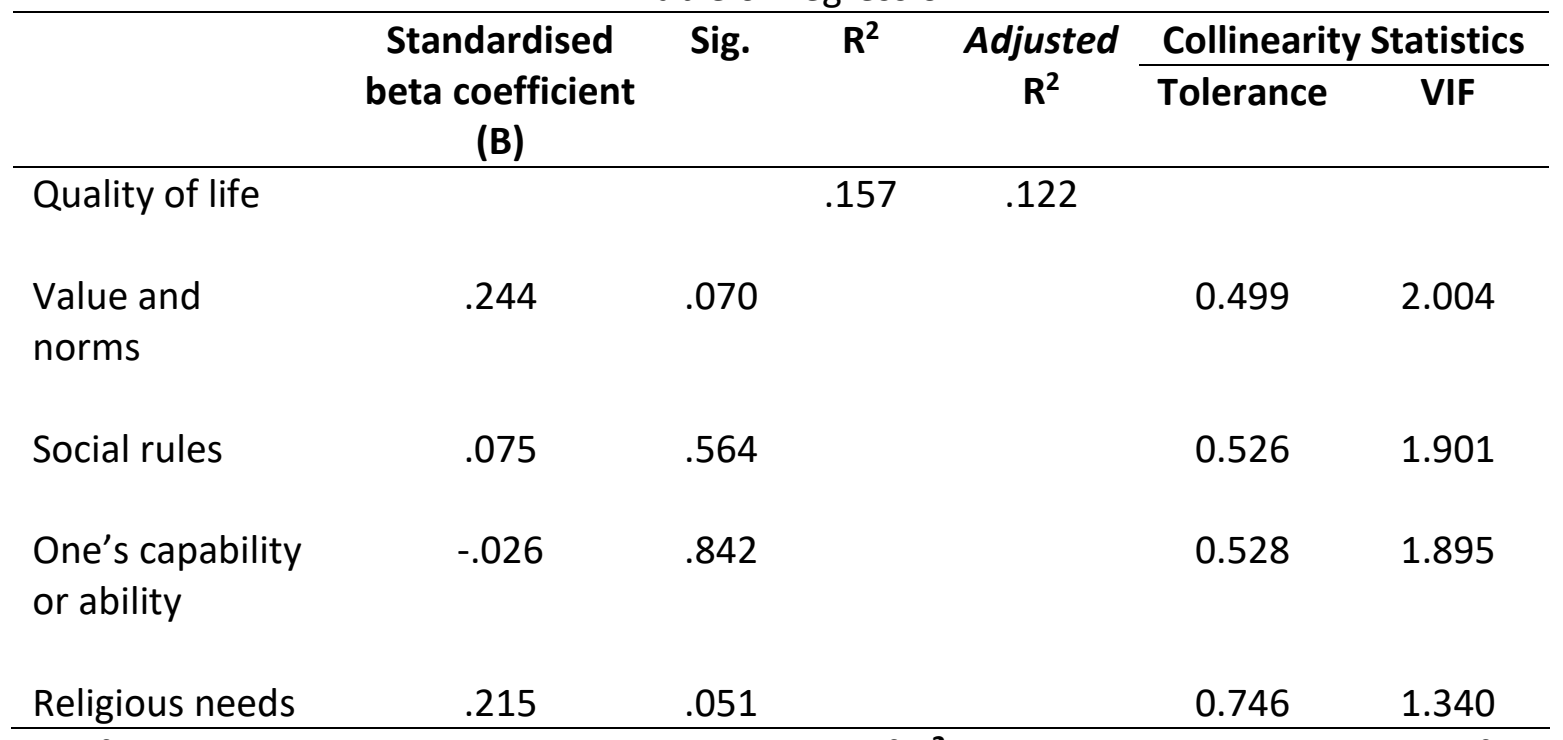

results of the regression analysis show that the value of $\mathbf{R}^{\mathbf{2}}$ is 0.157 . This shows that the influence of the social capital factor towards the respondents' quality of life is $15.7 \%$. According to Haynes (2010) and Colton \& Bower (2002), the regression model is still considered good even though the value of $\mathbf{R}^{\mathbf{2}}$ is less than $20 \%$ because this value is only an indicator of the regression model's completeness. Apart from the social capital factors studied, there may be other factors that are able to influence the respondents' quality of life.

\section{Conclusion}

From this study, it can be concluded that the level of social capital, mental health and quality of life for the B40 group in Kuala Terengganu is at a high level. Apart from that, in efforts to improve the quality of life from the B40 group, the factor of social capital, that is value, norms, social rules, one's capability and ability, and religious needs have to be given attention to. This is because the results from this study also show that these factors can also contribute to the quality of life of the respondents. Mental health also has a role to play, as mentioned in the above study. The objective of this study was successfully achieved, that is to the influence of social capital and mental health on the quality of life of the low income group B40. 
INTERNATIONAL JOURNAL OF ACADEMIC RESEARCH IN BUSINESS AND SOCIAL SCIENCES

Vol. 8, No. 9, Sept. 2018, E-ISSN: 2222-6990 @ 2018 HRMARS

The results of this study consistent with the study by Gittell et al. (2001) conclude that social capital plays an important role in achieving economic for a society. Therefore, the state holders are able to utilize this finding as a framework for development of strategies, programmes and activities for the betterment of communities.

\section{Acknowledgement}

This project has been funding from the Ministry of Education Malaysia via the Research Grant Scheme FRGS (FRGS / 1/2017 / SS06 / UniSZA / 01/1 / RR243).

\section{Corresponding Author}

Zainul Zolkifeli,

Faculty of Applied Social Sciences,

Universiti Sultan Zainal Abidin, Malaysia

Email: zainulzolkifeli@gmail.com

\section{References}

Bjørnskov, C., \& Svendsen, G. T. (2003). Measuring Social Capital - Is There A Single Underlying Explanation? Working Papers 03-5. Aarhus, Denmark. Retrieved from http://ideas.repec.org/p/hhs/aareco/2003_005.html

Bullen, P., \& Onyx, J. (2005). Measuring Social Capital in Five Communities in NSW: A Practitioner's Guide (Second Edi). Coogee NSW, Australia: Management Alternatives Pty Ltd.

Retrieved from http://library.bsl.org.au/jspui/bitstream/1/4141/1/Measuring social capital in 5 communities in NSW_Bullen\%260nyx 2005.pdf

Calvert, G. and Henderson, H. (2005). The Calvert-Henderson quality of life indicators, http://www.calvert-henderson.com/

Coakes, S. J., \& Steed, L. (2007). SPSS: Analysis Without Anguish: Version 14.0 for Windows. Milton, Queensland: John Wiley \& Sons.

Colton, J.A. \& Bower, K.M. (2002). Some msiconceptions about about $\mathbf{R}^{\mathbf{2}}$. International Society of Six Sigma Professionals, EXTRA Ordinary Sense, 3(2), 20-22.

De Silva, M.J., McKenzie, K., Harpham, T., Huttly SR, J., Epidemiol (2005) Community Health. Aug;59(8):619-27. Review. PMID: 16020636

Grootaert, C., Narayan, D., Jones, V. N., \& Woolcock, M. (2004). Measuring Social Capital : An Integrated Questionnaire (Vol. 18). Washington, D.C.

Haynes, R. (2010). The Value of R-squared in Regression (it is minor). http://www.smartersolutions.com/blog/wordpress/2010/04/02/the-value-of-r-squared-in-

regression-it-is-minor/

HealthPro, (2000). Buletin Jabatan Kesihatan Masyarakat (HUKM). Vol.1, No.3.

Mohd Shaladdin, M., Wan Abdul Aziz, W. M. A., \& Nik Wan, O. (2009). Analisis Kesejahteraan Hidup Nelayan Pesisir. Jurnal Kemanusiaan, 8, 58-77.

Mohd Yusof, H., Azima, A. M., Zaimah, R., \& Suhana, S. (2011). Kesejahteraan Sosial Masyarakat Nelayan: Kajian Kes di Kampung Sri Bahagia, Mersing, Johor. Geografia Online Malaysia Journal of Society and Space, 7(Special Issue : Social and Spatial Challenges of Malaysian 
INTERNATIONAL JOURNAL OF ACADEMIC RESEARCH IN BUSINESS AND SOCIAL SCIENCES

Vol. 8, No. 9, Sept. 2018, E-ISSN: 2222-6990 @ 2018 HRMARS

Development), 80-90. Retrieved from http://www.ukm.my/geografia

Nieboer, A., Lindenberg, S., Boomsma, A. and Van Bruggen, A.C., (2005). Dimensions of wellbeing and their measurement: The spf-II scale, Social Indicators Research, 73(3): 313353.

Noorasiah, S., \& Mohd Nasir, M. S. (2007). Modal Sosial dalam Mempertingkat Daya Saing Firma Perusahaan Kecil dan Sederhana (PKS). International Journal of Molecular Sciences, 14(2), 93-111. Retrieved from http://ijms.uum.edu.my/images/pdf1/14no2ijms/ijms1426.pdf

Nor Hamizah, A. R. (2016). Faktor Demografi dan Sosio-Ekonomi Kumpulan B40 dalam Pemilikan Takaful Keluarga/Insurans Hayat. Proceeding of the 2nd International Conference on Economics \& Banking 2016 (2nd ICEB), 2016(2), 978-967. Retrieved from http://conference.kuis.edu.my/iceb2016/eproceedings/EB003.pdf

Ghani, N. A. (2003). Kualiti hidup penduduk pulau Negeri Terengganu: Satu kajian di Pulau Redang dan Pulau Perhentian, Tesis Ph.D, Kolej Universiti Sains dan Teknologi Malaysia.

Pollnac, R.B, Pomeroy, R.S, and Harkes, I.H.T., (2001). Fishery policy and job satisfaction in three Southeast Asian fisheries, Ocean and Coastal Management 44: 531-544.

Rahmah, I., Noor Dzaharah, M., \& Noorasiah, S. (2016). Tahap dan Penentu Indeks Modal Sosial di Malaysia. Kajian Malaysia, 34(2), 101-121. https://doi.org/10.21315/km2016.34.2.5

Sekaran, U. (2003). Research Methods for Business: A Skill-Building Approach (4th editio). John Wiley \& Sons, Inc.

Rahman, S. F. A. (2006). Kriteria kualiti hidup berkeluarga, http://www.ikim.gov.my/bm/paparmedia.php?key=781, pada 25/1/2006.

Sudarsky, J. D. (1999). Columbia's Social Capital: The National Measurement with the Barcas. Colombia.Retrievedfromhttp://siteresources.worldbank.org/INTSOCIALCAPITAL/Resour ces/400219-1150464137254/sudarsky.pdf

Swami V, Chamorro-Premuzic T, Sinniah D, Maniam T, Kannan K, Stanistreet D, Furnham A.Soc Psychiatry Psychiatr Epidemiol. (2007) Feb;42(2):161-6. Epub 2006 Dec 18. PMID: 17180631

Warr, P. B. (1987). Work, Unemployment and Mental Health. Oxford: Oxford Science Publications.

World Health Organization, World Health Report (2003). Shaping the future. World Health Organization: Geneva, 2003. 